\title{
Human genetic basis of fulminant viral hepatitis
}

\author{
Emmanuelle Jouanguy ${ }^{1,2,3}$ (1)
}

Received: 14 January 2020 / Accepted: 4 April 2020 / Published online: 13 April 2020

(c) Springer-Verlag GmbH Germany, part of Springer Nature 2020

\begin{abstract}
In rare cases, hepatitis A virus (HAV) and hepatitis B virus (HBV) can cause fulminant viral hepatitis (FVH), characterized by massive hepatocyte necrosis and an inflammatory infiltrate. Other viral etiologies of FVH are rarer. FVH is life-threatening, but the patients are typically otherwise healthy, and normally resistant to other microbes. Only a small minority of infected individuals develop FVH, and this is the key issue to be addressed for this disease. In mice, mouse hepatitis virus 3 (MHV3) infection is the main model for dissecting FVH pathogenesis. Susceptibility to MHV3 differs between genetic backgrounds, with high and low mortality in C57BL6 and A/J mice, respectively. FVH pathogenesis in mice is related to uncontrolled inflammation and fibrinogen deposition. In humans, FVH is typically sporadic, but rare familial forms also exist, suggesting that there may be causal monogenic inborn errors. A recent study reported a single-gene inborn error of human immunity underlying FVH. A patient with autosomal recessive complete IL-18BP deficiency was shown to have FVH following HAV infection. The mechanism probably involves enhanced IL-18- and IFN- $\gamma$-dependent killing of hepatocytes by NK and CD8 T cytotoxic cells. Proof-of-principle that FVH can be genetic is important clinically, for the affected patients and their families, and immunologically, for the study of immunity to viruses in the liver. Moreover, the FVH-causing IL18BP genotype suggests that excessive IL-18 immunity may be a general mechanism underlying FVH, perhaps through the enhancement of IFN- $\gamma$ immunity.
\end{abstract}

\section{Introduction}

Acute liver failure (ALF) is a life-threatening condition characterized by massive necrosis of the liver in humans. Clinical manifestations include a severe impairment of hepatic function, with progressive jaundice, disturbed coagulation, and encephalopathy developing within 8 weeks of the onset of the first symptoms and signs, at least in individuals without preexisting liver disease. The main causes of ALF are diverse and include paracetamol toxicity, metabolic disorders (such as Wilson's disease), autoimmune diseases, and infection with liver-tropic viruses, also known as fulminant

Emmanuelle Jouanguy

emmanuelle.jouanguy@inserm.fr

1 Laboratory of Human Genetics of Infectious Diseases, Necker Branch, Institut National de la Santé et de la Recherche Médicale (INSERM) UMR-1163, Necker Hospital for Sick Children, Paris, France

2 Imagine Institute, Paris University, Paris, France

3 St. Giles Laboratory of Human Genetics of Infectious Diseases, Rockefeller Branch, Rockefeller University, New York, NY, USA viral hepatitis (FVH) (Stravitz and Lee 2019; Bernal and Wendon 2013; Bernal et al. 2010; Ganger et al. 2018; Kathemann et al. 2015; Ichai and Samuel 2008). Around 5\% of all cases of ALF remain unexplained (Ganger et al. 2018). The percentage of ALF due to viral infections ranges from 10 to $45 \%$ depending on geographic area (Stravitz and Lee 2019; Colleti Junior et al. 2019). Hepatitis A virus (HAV) and hepatitis B virus (HBV) are the liver-tropic viruses most frequently implicated in FVH (Liu et al. 2001; European Association for the Study of the Liver 2017). Other viruses, such as herpes viruses, may be involved to a lesser extent. The current prevalence and incidence of FVH worldwide are not precisely known, but previous studies have suggested that FVH develops in no more than $0.5 \%$ and $0.1 \%$ of individuals with symptomatic HAV (Lemon et al. 2018) and HBV (Asgari et al. 2019) infections, respectively. The outcome is poor, with fewer than $20 \%$ of patients surviving in the absence of liver transplantation. By contrast, survival rates may reach $80 \%$ after liver transplantation (Lemon et al. 2018; Bernal et al. 2015). Very little is known about the pathogenesis of FVH. Its rarity and typically sporadic nature suggested that the causal viruses were unlikely to be abnormally virulent (Ajmera et al. 2011; Fujiwara et al. 2001; Sato 
et al. 2003). Several groups have reported the more frequent occurrence of some HBV mutations in patients with FVH than in patients with other forms of HBV infection (Sainokami et al. 2007; Ozasa et al. 2006; Friedt et al. 1999). Conversely, reports of rare multiplex and/or consanguineous families have suggested a possible contribution of inborn errors of immunity (IEI) (Durst et al. 2001; Yalniz et al. 2005; Yoshida et al. 2017). Moreover, single-gene IEI have been found to underlie other severe, isolated viral infections, such as herpes simplex virus encephalitis, attenuated live measles and yellow fever vaccine diseases, Kaposi sarcoma, severe influenza pneumonitis, epidermodysplasia verruciformis, and fulminant EBV disease (Byun et al. 2013; Ciancanelli et al. 2015, 2016; Jong et al. 2018a, b; Hernandez et al. 2018, 2019; Jackson et al. 2016; Tangye and Latour 2020; Zhang and Casanova 2015; Zhang et al. 2018, 2019; Lafaille et al. 2012, 2015; Latour and Fischer 2019). These observations suggest that FVH may be caused by a liver IEI to viruses. Here, we review the mouse and human genetic studies leading to the recent discovery of the first inborn error of liver immunity to viruses.

\section{Genetic studies in mice}

Human hepatitis viruses are not natural pathogens of mice. Alternative infectious and non-infectious mouse models have, therefore, been developed, for dissection of the pathogenesis of FVH. The most common infectious model of hepatitis is based on viruses from the mouse hepatitis virus (MHV) family. These viruses are coronaviruses, which resemble HAV in being single-stranded (+) RNA viruses, but differ from HAV in having an envelope. MHVs differ in tissue tropism and virulence, with the hepatotropic viruses MHV3 and MHVA59 having high and low virulence, respectively (Le Prevost et al. 1975a; Wijburg et al. 1997). In mice, MHV3 infection leads to a spectrum of hepatic phenotypes, ranging from high susceptibility to complete resistance, depending on genetic background. The BALB/c and C57BL6 strains are both highly susceptible to MHV3 infection, whereas the A/J strain is resistant, except during the neonatal period (Le Prevost et al. 1975b; Tardieu et al. 1980; Levy et al. 1981). A cytopathic effect of the virus is not the only explanation for this, as viral replication in hepatocytes is similar in susceptible and resistant mice (Taguchi et al. 1983; Levy et al. 1983). Hepatic failure is the major disorder observed in susceptible mice, but hepatocytes are not the only cells targeted by MHV3. This virus also replicates in endothelial (sinusoidal and vascular) and immunological cells (hepatic macrophages, also known as Kupffer cells, and natural killer (NK) cells) (Pereira et al. 1984). MHV3 infection has been studied for decades, both genetically and immunologically, to decipher the spectrum of infectious phenotypes (Le Prevost et al. 1975a).

In the 1970s, macrophages and lymphocytes (Tardieu et al. 1980) were reported to be involved in the anti-MHV3 immune response, together with type I (in vivo) and type II (in vitro) interferons (IFNs) (Virelizier et al. 1976; 1977; Virelizier and Gresser 1978). In 1979, Levy-Leblond et al. showed, by crossing MHV3-resistant and MHV3-susceptible mouse strains, that acute liver disease was determined by one or two genes unrelated to the $\mathrm{H}-2$ complex with a recessive mode of inheritance (Levy-Leblond et al. 1979). A few years later, another group published results confirming the model of two recessive genes unrelated to the $\mathrm{H}-2$ locus (Dindzans et al. 1986). They also established a link between susceptibility to MHV3 infection and the level of macrophage procoagulant activity (PCA) (Dindzans et al. 1986). This link was confirmed by the treatment of susceptible mice with a neutralizing antibody against MHV3induced PCA, which rendered these mice resistant, and by the induction of PCA in resistant mice, which rendered them susceptible (Li et al. 1992; Fingerote et al. 1996). Following molecular cloning, the $\mathrm{Fgl} / 2$ gene was identified as encoding an interferon (IFN) $\gamma$-inducible fibrinogen-like protein, responsible for macrophage PCA (Levy et al. 1981; Qureshi et al. 1995; Parr et al. 1995a, b). Its expression promotes fibrinogen deposition, leading to the activation of coagulation cascades and PCA. By contrast to the nucleocapsid proteins of non-hepatotropic MVHs, the nucleocapsid (N) protein of MHV3 and MHVA59 is required for the induction of $\mathrm{Fgl} 2$ expression, through the binding of the transcription factor hepatic nuclear factor 4 to the $\mathrm{Fgl} 2$ promoter (Ning et al. 1999; 2003) Finally, following MHV3 infection, Fgl2knockout (KO) mice display milder disease and lower mortality than wild-type mice, suggesting a key role for FGL2 in the pathogenesis of MHV3-induced FVH (Marsden et al. 2003).

Reverse genetics techniques have been used to dissect out the mechanism of MHV3-induced FVH in greater detail. A few KO mice have been tested, some of which were more susceptible than WT mice, with earlier and higher mortality. These models included knockouts of programmed death (PD)-1, IL-33 and V-set immunoglobulin domain-containing 4 (VSIG4) (Carriere et al. 2017; Chen et al. 2011; Li et al. 2017). PD-1 modulates the balance between the antimicrobial immune response and immune system-mediated tissue damage. IFN $\gamma$ and $\mathrm{TNF} \alpha$ are more strongly induced in PD-1-KO mice than in WT mice, leading to higher levels of FGL2 secretion and greater tissue damage. Treatments blocking IFN $\gamma$ and TNF $\alpha$ decrease mortality in PD-1-KO mice, suggesting a role for these two cytokines in the pathogenesis of MHV3-induced FVH (Chen et al. 2011). IL-33 is a ubiquitously and constitutively expressed cytokine. It 
belongs to the IL-1 family and has pleiotropic functions, including IFN $\gamma$ induction and inflammatory effects (Carriere et al. 2017). MHV3 infection in IL-33-KO mice is associated with an increase in neutrophil recruitment and a lack of infiltrating NK cells, T cells, and macrophages (Carriere et al. 2017). These mice display lower levels of IFN $\gamma$ induction, but much higher levels of TNF $\alpha$ and IL-6 induction than WT mice during infection. Finally, VSIG4 is a complement receptor of the immunoglobulin superfamily. It is expressed exclusively in tissue macrophages, including Kupffer cells. Inflammatory cytokines, not only such as IFN $\gamma$ and TNF $\gamma$ but also FGL2, are strongly induced in VSIG4-KO mice, leading to uncontrolled macrophage-mediated inflammation and tissue damage (Li et al. 2017).

By contrast, other KO mice become resistant to MHV3induced FVH. For example, mortality was shown to be much lower in B- and T-lymphocyte attenuator (BTLA)KO mice than in their WT littermates (Yang et al. 2013). This resistant phenotype is related to a lack of FGL2 induction, resulting in lower levels of fibrinogen deposition and tissue damage. Despite similar levels of IFN $\gamma$ and TNF $\alpha$ production in WT and BLTA-KO mice, macrophage apoptosis rates were higher in BTLA-KO mice, and a smaller number of these macrophages infiltrated the liver (Yang et al. 2013). TNF $\alpha-\mathrm{KO}$ mice were also found to have a resistant phenotype, due to lower levels of FGL2 induction (Yang et al. 2013). In another study, C5aR-KO mice were found to be resistant to MHV3-induced FVH, with lower mortality, reflecting lower levels of TNF $\alpha$, IL6 and FGL2 induction, whereas IFN $\gamma$ production was similar to that in WT mice (Liu et al. 2015). Interestingly, macrophage scavenger receptor 1 (MSR1)-KO mice were less susceptible to MHVA59-induced FVH. The authors reported a lower induction of inflammatory cytokines (TNF $\alpha$, IL-6 and IFN $\gamma$ ) and lower levels of FGL2 and C5a secretion (Tang et al. 2018). FLG2- and TNF $\alpha-K O$ mice were confirmed to be resistant to infection, whereas IL-6-KO mice have a phenotype similar to that of WT mice (Liu et al. 2015). Finally, TLR2 is strongly induced during MHV3 infection, as are IL6, IL33 and TNFo (Li et al. 1992). TLR2-KO mice are less susceptible to MHV3 infection than WT mice, with lower levels of viral replication and liver damage, and delayed mortality. These findings reflect lower levels of inflammatory cytokine production, but not of FGL2 production, together with a delayed recruitment of neutrophils, macrophages and NK cells (Bleau et al. 2016). Overall, they suggest that, in the mouse model, MHVA59- or MHV3-induced FHV results from uncontrolled PCA due to high levels of inflammation and macrophage activation, leading to high levels of fibrinogen deposition and tissue damage.

\section{Genetic studies in humans}

Very little is known about the pathogenesis of human FVH. The human FGL2 gene was identified following studies in mice (Levy et al. 2000). In patients with FVH due to HBV, FGL2 is strongly expressed in macrophages in liver tissue, as observed in the mouse model. Plasma concentrations of FGL2, IFN $\gamma$, IL- $1 \beta$, and IL-18 are higher in patients with FVH than in healthy or chronically infected individuals without FVH (Liu et al. 2015; Shinoda et al. 2006; Yumoto et al. 2002; Zhu et al. 2005). Activated $\mathrm{CD} 68^{+}$macrophages have been detected in areas of active necrosis (Levy et al. 2000). The serum viral load in patients with FVH due to HAV or HBV is similar to or lower than that in patients with acute benign HAV or HBV hepatitis (Sainokami et al. 2007; Ozasa et al. 2006; Rezende et al. 2003). These observations suggest that the clinical phenotype is probably due more to a lack of inflammation regulation than to a lack of control over viral replication. Interestingly, three multiplex families with FVH due to HAV have been described: an Iranian family with three previously healthy siblings $(17,19$ and 24 years old), a Turkish family including an affected brother and sister (16 and 18 years old), and a Japanese family with two affected brothers (59 and 63 years old) (Durst et al. 2001; Yalniz et al. 2005; Yoshida et al. 2017), consistent with genetic predisposition. Despite these findings, little is known about the pathogenesis of FVH in humans. Genetic studies have recently been performed on large cohorts of FVH patients, with either a candidate gene approach or a genome-wide approach. These studies yielded suggestive, but not conclusive findings.

A first human genetic study was published in 2011 by Kim et al. (2011). In this paper, the authors reported a case-control study on children from Argentina (30 children with FVH due to HAV and 102 controls) and one candidate gene TIMI, also known as HAVCRI, encoding the HAV receptor. They found a difference of borderline significance in the distribution of the 157insMTTTVP insertion between patients and controls ( $p$ value 0.037 ), with an allelic frequency of the insertion of $37 \%$ in patients and $28 \%$ in controls. This insertion leads to the production of an elongated form of the receptor. HAV infects hepatocytes expressing the short and long forms of this receptor with equal efficiency. However, NKT cells expressing the long form of TIM1 are more cytotoxic, potentially accounting for the rapid destruction of hepatocytes. This study was the first to investigate why only some HAV-infected individuals develop FVH. However, given the incidence of the disease, the allele frequency in the general population is too high to be compatible with the hypothesis of single-gene IEI, as previously reported in other severe viral 
diseases (Byun et al. 2013; Ciancanelli et al. 2015, 2016; Jong et al. 2018a, b; Hernandez et al. 2018, 2019; Jackson et al. 2016; Tangye and Latour 2020; Zhang and Casanova 2015; Zhang et al. 2018, 2019; Lafaille et al. 2012, 2015; Latour and Fischer 2019). In 2014, a second study was performed on a cohort of ten adult patients with acute liver injury or failure due to HAV. This study made use of a "hypothesis-free" strategy based on whole-genome sequencing. The authors initially analyzed their data under a hypothesis of genetic homogeneity, implying that one or several mutations of the same gene were common to most patients. No rare mutation meeting this criterion was detected under either the autosomal recessive (AR) or the autosomal dominant (AD) genetic model. Under a hypothesis of genetic heterogeneity, implying that each patient has a mutation of a different gene, the authors identified eight candidate genes, four under the AR model and four under the AD model, but no further functional investigations were performed to establish a genotype-phenotype correlation (Long et al. 2014).

More recently, two other genetic studies have been performed on cohorts of patients with FVH due to HBV. In 2018, Ajmera et al. compared exome data from 14 patients with $\mathrm{FVH}$, and 50 patients with chronic or acute (non-FVH) hepatitis to exome data for 2963 controls, all of European ancestry (Ajmera et al. 2019). They identified one singlenucleotide polymorphism (SNP), a missense mutation (rs2277680, A181V) in CXCL16, which was underrepresented in the FVH cohort relative to the others (only $9 \%$ of patients in the FVH cohort had a valine residue at position 181 (V181) vs. $43-50 \%$ in the others), including the controls, with a $p$ value of $8.8 \times 10^{-5}$. CXCL16 is a chemokine highly expressed in liver, especially on cholangiocytes, hepatocytes and hepatic endothelial cells, and it interacts with the CXCR6 receptor expressed on NKT cells. Functional studies have shown that the V181 allele cannot mediate monocyte adhesion ex vivo (Petit et al. 2011). Ajmera et al. hypothesized that the overrepresented A181 allele has a deleterious impact due to greater NKT cell adhesion, which may mediate hepatic inflammation, leading to massive destruction of the liver in FVH patients. In 2019, an association study on exome data compared 21 cases of FVH in adult patients to $172 \mathrm{HBV}^{+}$controls (Asgari et al. 2019). At the single-variant and gene-based levels, the analyses found no significant association. These results suggest various possibilities: predisposition to FVH may not be inherited, or may be caused by monogenic lesions in some patients, and perhaps digenic or oligogenic lesions in others, with a high degree of genetic heterogeneity (with patients carrying $\mathrm{FVH}$-causing variants of different genes).

In this context, we recently reported a child who died from FVH following infection with HAV who was homozygous for a private 40-nucleotide deletion in IL18BP, which encodes the IL-18-binding protein (IL-18BP) (Belkaya et al. 2019). Unlike the four non-synonymous variants of this gene found in the homozygous state in public databases, this variant is loss-of-function. IL18BP is a soluble antagonist of IL18, an inflammatory IFN $\gamma$-inducing cytokine that activates NK and T-cell cytotoxicity. IL18BP has a high affinity for IL18 and blocks the binding of this cytokine to its membrane-bound receptor, IL18R. IL-18 is hepatotoxic and was initially identified as the cytokine responsible for liver failure in the mouse model (Okamura et al. 1995; Tsutsui et al. 1992). Human IL-18 and IL-18BP are both produced by hepatocytes and macrophages, which are destroyed and highly activated, respectively, during FVH. We have shown that, in the absence of IL-18BP, excessive NK cell activation by IL-18 results in the uncontrolled killing of human hepatocytes in vitro. We suggest that the lack of negative regulation of IL-18 by IL-18BP in vivo leads to the enhanced activation and production of IFN- $\gamma$ by $\mathrm{NK}$ and $\mathrm{T}$ lymphocytes in patients, resulting in the activation of macrophages and hepatocyte killing (Fig. 1). Inherited human IL-18BP deficiency thus underlies fulminant HAV hepatitis by unleashing IL-18, and possibly IFN- $\gamma$. These findings suggest that human IL-18 is toxic to the liver and that IL-18BP is its antidote.

\section{Conclusion}

In conclusion, the discovery of IL-18BP deficiency as a genetic etiology of FVH provided proof-of-principle that FVH can be caused by single-gene inborn errors selectively disrupting liver-specific immunity to viruses. It also points to IL-18 as an anchor molecule in the pathogenesis of FVH. The massive killing of hepatocytes due to uncontrolled inflammation seems to be the mechanism underlying the pathogenesis of FVH. However, the genetic and mechanistic dissection of FVH pathogenesis remains in its infancy. Further studies are required to determine, in more detail, the roles of hematopoietic cells (cytotoxic lymphocytes, macrophages) and non-hematopoietic cells (hepatocytes) in the establishment of FVH. The discovery of an IEI underlying FVH is important from a clinical standpoint, as it makes it possible to deliver a diagnosis to patients and their families, and from an immunological standpoint, as it will facilitate the deciphering of liverintrinsic immunity. These studies may pave the way for the development of novel preventive or therapeutic interventions. Recombinant human IL-18BP (Tadekinig Alfa; AB2 Bio) has been proposed as a treatment for preventing acetaminophen hepatotoxicity (Bachmann et al. 2018). There may be other ways to manage patients who would die from infection without liver transplantation, a procedure that remains associated with heavy short- and long-term morbidity and mortality. The discovery of novel genetic etiologies of FVH may also pave the 


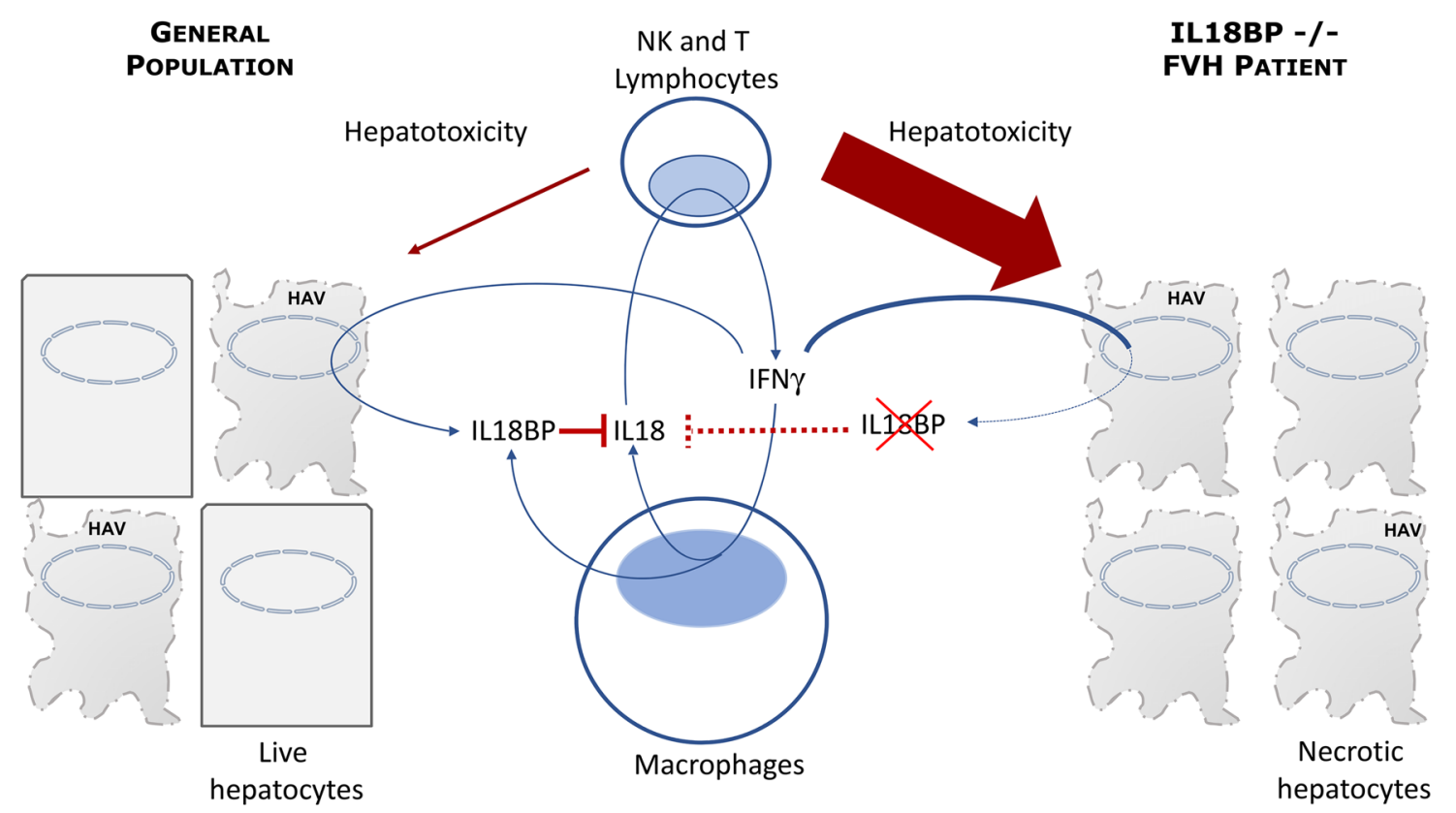

Fig. 1 Schematic model of FVH pathogenesis in IL18BP deficiency. Following HAV infection in a healthy individual, IL-18 is secreted by macrophages in the liver. This cytokine activates NK and T lymphocytes, inducing IFN- $\gamma$ production and cytotoxicity to eliminate

way for the development of a new treatment for other forms of fulminant hepatitis, such as acetaminophen-induced hepatitis, and, perhaps, chronic hepatitis.

Acknowledgements I thank the patients and their families for their participation in our studies. I thank Charles M. Rice and Jean-François Emile for their collaboration; Jean-Laurent Casanova and Laurent Abel for their support; Serkan Belkaya, Cécilia Korol and Lazaro Lorenzo for their work on this project; Aurélie Cobat for critical reading, all members of both branches of the St. Giles Laboratory of Human Genetics of Infectious Diseases for helpful discussions and Dominick Papandrea, Cécile Patissier, and Yelena Nemirovskaya for administrative assistance. This work was funded, in part, by the National Center for Advancing Translational Sciences (NCATS), National Institutes of Health (NIH) Clinical and Translational Science Award (CTSA) program (UL1TR001866), National Institute of Allergy and Infectious Diseases (NIAID) for a Cooperative Center on Human Immunology (CCHI) pilot award (U19AI111825), Jeffrey Modell Foundation's Specific Defect Research Program, the French National Research Association for AIDS (ANRS, \#ECTZ66106 and \#ECTZ77975), the French Medical Research Foundation (FRM, \#EQU201903007798), the French National Research Agency (ANR) under the "Investments for the future" program (ANR-10-IAHU-01), and NKD (ANR-15-CE15-0013), the Rockefeller University, Institut National de la Santé et de la Recherche Médicale (INSERM), the Howard Hughes Medical Institute, Paris Descartes University, and the St. Giles Foundation.

\section{References}

Ajmera V, Huang H, Dao D, Feld JJ, Lau DT, Patel K, Rule JA, Daly M, Lee WM, Chung RT (2019) Host genetic variant in CXCL16
HAV-infected cells. IFN- $\gamma$ also induces IL-18BP secretion by hepatocytes and macrophages to antagonize IL-18 activity. However, in the absence of IL-18BP, excessive IL-18 activity leads to uncontrolled, massive immune-mediated hepatotoxicity and severe liver injury

may be associated with hepatitis B virus-related acute liver failure. Cell Mol Gastroenterol Hepatol 7:477-479

Ajmera V, Xia G, Vaughan G, Forbi JC, Ganova-Raeva LM, Khudyakov Y, Opio CK, Taylor R, Restrepo R, Munoz S, Fontana RJ, Lee WM, Acute Liver Failure Study G (2011) What factors determine the severity of hepatitis A-related acute liver failure? J Viral Hepat 18:e167-e174

Asgari S, Chaturvedi N, Scepanovic P, Hammer C, Semmo N, Giostra E, Mullhaupt B, Angus P, Thompson AJ, Moradpour D, Fellay J (2019) Human genomics of acute liver failure due to hepatitis B virus infection: an exome sequencing study in liver transplant recipients. J Viral Hepat 26:271-277

Bachmann M, Pfeilschifter J, Muhl H (2018) A prominent role of interleukin-18 in acetaminophen-induced liver injury advocates its blockage for therapy of hepatic necroinflammation. Front Immunol 9:161

Belkaya S, Michailidis E, Korol CB, Kabbani M, Cobat A, Bastard P, Lee YS, Hernandez N, Drutman S, de Jong YP, Vivier E, Bruneau J, Beziat V, Boisson B, Lorenzo-Diaz L, Boucherit S, Sebagh M, Jacquemin E, Emile JF, Abel L, Rice CM, Jouanguy E, Casanova JL (2019) Inherited IL-18BP deficiency in human fulminant viral hepatitis. J Exp Med 216:1777-1790

Bernal W, Auzinger G, Dhawan A, Wendon J (2010) Acute liver failure. Lancet 376:190-201

Bernal W, Lee WM, Wendon J, Larsen FS, Williams R (2015) Acute liver failure: a curable disease by 2024? J Hepatol 62:S112-S120

Bernal W, Wendon J (2013) Acute liver failure. N Engl J Med 369:2525-2534

Bleau C, Burnette M, Filliol A, Piquet-Pellorce C, Samson M, Lamontagne L (2016) Toll-like receptor-2 exacerbates murine acute viral hepatitis. Immunology 149:204-224

Byun M, Ma CS, Akçay A, Pedergnana V, Palendira U, Myoung J, Avery D, Liu Y, Abhyankar A, Lorenzo L, Schmidt M, Lim H, Cassar O, Migaud M, Rozenberg F, Canpolat N, Aydogan G, 
Fleckenstein B, Bustamante J, Picard C, Gessain A, Jouanguy E, Cesarman E, Olivier M, Gros P, Abel L, Croft M, Tangye SG, Casanova JL (2013) Inherited human OX40 deficiency underlying classic Kaposi sarcoma in childhood. J Exp Med 210:1743-1759

Carriere V, Arshad MI, Le Seyec J, Lefevre B, Farooq M, Jan A, Manuel C, Touami-Bernard L, Lucas-Clerc C, Genet V, Gascan H, Girard JP, Chalmel F, Lamontagne L, Piquet-Pellorce C, Samson M (2017) Endogenous IL-33 deficiency exacerbates liver injury and increases hepatic influx of neutrophils in acute murine viral hepatitis. Mediat Inflamm 2017:1359064

Chen Y, Wu S, Guo G, Fei L, Guo S, Yang C, Fu X, Wu Y (2011) Programmed death (PD)-1-deficient mice are extremely sensitive to murine hepatitis virus strain-3 (MHV-3) infection. PLoS Pathog 7:e1001347

Ciancanelli MJ, Abel L, Zhang SY, Casanova JL (2016) Host genetics of severe influenza: from mouse Mx1 to human IRF7. Curr Opin Immunol 38:109-120

Ciancanelli MJ, Huang SX, Luthra P, Garner H, Itan Y, Volpi S, Lafaille FG, Trouillet C, Schmolke M, Albrecht RA, Israelsson E, Lim HK, Casadio M, Hermesh T, Lorenzo L, Leung LW, Pedergnana V, Boisson B, Okada S, Picard C, Ringuier B, Troussier F, Chaussabel D, Abel L, Pellier I, Notarangelo LD, Garcia-Sastre A, Basler CF, Geissmann F, Zhang SY, Snoeck HW, Casanova JL (2015) Infectious disease. Life-threatening influenza and impaired interferon amplification in human IRF7 deficiency. Science 348:448-453

Colleti Junior J, Caino FR, Teixeira R, Carvalho WB (2019) Fulminant acute hepatitis in pediatrics in Latin America and the Caribbean. Rev Assoc Med Bras 1992(65):914-921

de Jong SJ, Crequer A, Matos I, Hum D, Gunasekharan V, Lorenzo L, Jabot-Hanin F, Imahorn E, Arias AA, Vahidnezhad H, Youssefian L, Markle JG, Patin E, D’Amico A, Wang CQF, Full F, Ensser A, Leisner TM, Parise LV, Bouaziz M, Maya NP, Cadena XR, Saka B, Saeidian AH, Aghazadeh N, Zeinali S, Itin P, Krueger JG, Laimins L, Abel L, Fuchs E, Uitto J, Franco JL, Burger B, Orth G, Jouanguy E, Casanova JL (2018a) The human CIB1-EVER1EVER2 complex governs keratinocyte-intrinsic immunity to betapapillomaviruses. J Exp Med 215:2289-2310

de Jong SJ, Imahorn E, Itin PH, Uitto J, Orth G, Jouanguy E, Casanova J-L, Burger B (2018b) Epidermodysplasia verruciformis: inborn errors of immunity to human beta-papillomaviruses. Front Microbiol 9:1222

Dindzans VJ, Skamene E, Levy GA (1986) Susceptibility/resistance to mouse hepatitis virus strain 3 and macrophage procoagulant activity are genetically linked and controlled by two non-H-2-linked genes. J Immunol 137:2355-2360

Durst RY, Goldsmidt N, Namestnick J, Safadi R, Ilan Y (2001) Familial cluster of fulminant hepatitis A infection. J Clin Gastroenterol $32: 453-454$

European Association for the study of the Liver (2017) EASL Clinical Practical Guidelines on the management of acute (fulminant) liver failure. J Hepatol 66:1047-1081

Fingerote RJ, Abecassis M, Phillips MJ, Rao YS, Cole EH, Leibowitz J, Levy GA (1996) Loss of resistance to murine hepatitis virus strain 3 infection after treatment with corticosteroids is associated with induction of macrophage procoagulant activity. J Virol 70:4275-4282

Friedt M, Gerner P, Lausch E, Trubel H, Zabel B, Wirth S (1999) Mutations in the basic core promotor and the precore region of hepatitis B virus and their selection in children with fulminant and chronic hepatitis B. Hepatology 29:1252-1258

Fujiwara K, Yokosuka O, Fukai K, Imazeki F, Saisho H, Omata M (2001) Analysis of full-length hepatitis A virus genome in sera from patients with fulminant and self-limited acute type A hepatitis. J Hepatol 35:112-119
Ganger DR, Rule J, Rakela J, Bass N, Reuben A, Stravitz RT, Sussman N, Larson AM, James L, Chiu C, Lee WM, Acute Liver Failure Study G (2018) Acute liver failure of indeterminate etiology: a comprehensive systematic approach by an expert committee to establish causality. Am J Gastroenterol 113:1319

Hernandez N, Bucciol G, Moens L, Le Pen J, Shahrooei M, Goudouris E, Shirkani A, Changi-Ashtiani M, Rokni-Zadeh H, Sayar EH, Reisli I, Lefevre-Utile A, Zijlmans D, Jurado A, Pholien R, Drutman S, Belkaya S, Cobat A, Boudewijns R, Jochmans D, Neyts J, Seeleuthner Y, Lorenzo-Diaz L, Enemchukwu C, Tietjen I, Hoffmann HH, Momenilandi M, Poyhonen L, Siqueira MM, de Lima SMB, de Souza Matos DC, Homma A, Maia MLS, da Costa Barros TA, de Oliveira PMN, Mesquita EC, Gijsbers R, Zhang SY, Seligman SJ, Abel L, Hertzog P, Marr N, Martins RM, Meyts I, Zhang Q, MacDonald MR, Rice CM, Casanova JL, Jouanguy E, Bossuyt X (2019) Inherited IFNAR1 deficiency in otherwise healthy patients with adverse reaction to measles and yellow fever live vaccines. J Exp Med 216:2057-2070

Hernandez N, Melki I, Jing H, Habib T, Huang SSY, Danielson J, Kula T, Drutman S, Belkaya S, Rattina V, Lorenzo-Diaz L, Boulai A, Rose Y, Kitabayashi N, Rodero MP, Dumaine C, Blanche S, Lebras MN, Leung MC, Mathew LS, Boisson B, Zhang SY, BoissonDupuis S, Giliani S, Chaussabel D, Notarangelo LD, Elledge SJ, Ciancanelli MJ, Abel L, Zhang Q, Marr N, Crow YJ, Su HC, Casanova JL (2018) Life-threatening influenza pneumonitis in a child with inherited IRF9 deficiency. J Exp Med 215:2567-2585

Ichai P, Samuel D (2008) Etiology and prognosis of fulminant hepatitis in adults. Liver Transpl 14(Suppl 2):S67-S79

Jackson CC, Dickson MA, Sadjadi M, Gessain A, Abel L, Jouanguy E, Casanova JL (2016) Kaposi sarcoma of childhood: inborn or acquired immunodeficiency to oncogenic HHV-8. Pediatr Blood Cancer 63:392-397

Kathemann S, Bechmann LP, Sowa JP, Manka P, Dechene A, Gerner P, Lainka E, Hoyer PF, Feldstein AE, Canbay A (2015) Etiology, outcome and prognostic factors of childhood acute liver failure in a German Single Center. Ann Hepatol 14:722-728

Kim HY, Eyheramonho MB, Pichavant M, Gonzalez Cambaceres C, Matangkasombut P, Cervio G, Kuperman S, Moreiro R, Konduru K, Manangeeswaran M, Freeman GJ, Kaplan GG, DeKruyff RH, Umetsu DT, Rosenzweig SD (2011) A polymorphism in TIM1 is associated with susceptibility to severe hepatitis A virus infection in humans. J Clin Investig 121:1111-1118

Lafaille FG, Ciancanelli MJ, Studer L, Smith G, Notarangelo L, Casanova JL, Zhang SY (2015) Deciphering human cell-autonomous anti-HSV-1 immunity in the central nervous system. Front Immunol 6:208

Lafaille FG, Pessach IM, Zhang SY, Ciancanelli MJ, Herman M, Abhyankar A, Ying SW, Keros S, Goldstein PA, Mostoslavsky G, Ordovas-Montanes J, Jouanguy E, Plancoulaine S, Tu E, Elkabetz Y, Al-Muhsen S, Tardieu M, Schlaeger TM, Daley GQ, Abel L, Casanova JL, Studer L, Notarangelo LD (2012) Impaired intrinsic immunity to HSV-1 in human iPSC-derived TLR3-deficient CNS cells. Nature 491:769-773

Latour S, Fischer A (2019) Signaling pathways involved in the T-cellmediated immunity against Epstein-Barr virus: lessons from genetic diseases. Immunol Rev 291:174-189

Lemon SM, Ott JJ, Van Damme P, Shouval D (2018) Type A viral hepatitis: a summary and update on the molecular virology, epidemiology, pathogenesis and prevention. J Hepatol 68(1):167-184

Levy GA, Leibowitz JL, Edgington TS (1981) Induction of monocyte procoagulant activity by murine hepatitis virus type 3 parallels disease susceptibility in mice. J Exp Med 154:1150-1163

Levy GA, Liu M, Ding J, Yuwaraj S, Leibowitz J, Marsden PA, Ning Q, Kovalinka A, Phillips MJ (2000) Molecular and functional analysis of the human prothrombinase gene (HFGL2) and its role in viral hepatitis. Am J Pathol 156:1217-1225 
Levy GA, MacPhee PJ, Fung LS, Fisher MM, Rappaport AM (1983) The effect of mouse hepatitis virus infection on the microcirculation of the liver. Hepatology 3:964-973

Levy-Leblond E, Oth D, Dupuy JM (1979) Genetic study of mouse sensitivity to MHV3 infection: influence of the H-2 complex. J Immunol 122:1359-1362

Li J, Diao B, Guo S, Huang X, Yang C, Feng Z, Yan W, Ning Q, Zheng L, Chen Y, Wu Y (2017) VSIG4 inhibits proinflammatory macrophage activation by reprogramming mitochondrial pyruvate metabolism. Nat Commun 8:1322

Li C, Fung LS, Chung S, Crow A, Myers-Mason N, Phillips MJ, Leibowitz JL, Cole E, Ottaway CA, Levy G (1992) Monoclonal antiprothrombinase (3D4.3) prevents mortality from murine hepatitis virus (MHV-3) infection. J Exp Med 176:689-697

Liu M, Chan CW, McGilvray I, Ning Q, Levy GA (2001) Fulminant viral hepatitis: molecular and cellular basis, and clinical implications. Expert Rev Mol Med 2001:1-19

Liu J, Tan Y, Zhang J, Zou L, Deng G, Xu X, Wang F, Ma Z, Zhang J, Zhao T, Liu Y, Li Y, Zhu B, Guo B (2015) C5aR, TNF-alpha, and FGL2 contribute to coagulation and complement activation in virus-induced fulminant hepatitis. J Hepatol 62:354-362

Long D, Fix OK, Deng X, Seielstad M, Lauring AS, Acute Liver Failure Study G (2014) Whole-genome sequencing to identify host genetic risk factors for severe outcomes of hepatitis a virus infection. J Med Virol 86:1661-1668

Marsden PA, Ning Q, Fung LS, Luo X, Chen Y, Mendicino M, Ghanekar A, Scott JA, Miller T, Chan CW, Chan MW, He W, Gorczynski RM, Grant DR, Clark DA, Phillips MJ, Levy GA (2003) The Fgl2/fibroleukin prothrombinase contributes to immunologically mediated thrombosis in experimental and human viral hepatitis. J Clin Investig 112:58-66

Ning Q, Lakatoo S, Liu M, Yang W, Wang Z, Phillips MJ, Levy GA (2003) Induction of prothrombinase fgl2 by the nucleocapsid protein of virulent mouse hepatitis virus is dependent on host hepatic nuclear factor-4 alpha. J Biol Chem 278:15541-15549

Ning Q, Liu M, Kongkham P, Lai MM, Marsden PA, Tseng J, Pereira B, Belyavskyi M, Leibowitz J, Phillips MJ, Levy G (1999) The nucleocapsid protein of murine hepatitis virus type 3 induces transcription of the novel $\mathrm{fgl} 2$ prothrombinase gene. J Biol Chem 274:9930-9936

Okamura H, Tsutsi H, Komatsu T, Yutsudo M, Hakura A, Tanimoto T, Torigoe K, Okura T, Nukada Y, Hattori K et al (1995) Cloning of a new cytokine that induces IFN-gamma production by T cells. Nature 378:88-91

Ozasa A, Tanaka Y, Orito E, Sugiyama M, Kang JH, Hige S, Kuramitsu T, Suzuki K, Tanaka E, Okada S, Tokita H, Asahina Y, Inoue K, Kakumu S, Okanoue T, Murawaki Y, Hino K, Onji M, Yatsuhashi H, Sakugawa H, Miyakawa Y, Ueda R, Mizokami $M$ (2006) Influence of genotypes and precore mutations on fulminant or chronic outcome of acute hepatitis B virus infection. Hepatology 44:326-334

Parr RL, Fung L, Reneker J, Myers-Mason N, Leibowitz JL, Levy G (1995a) MHV-3 induced prothrombinase is encoded by musfiblp. Adv Exp Med Biol 380:151-157

Parr RL, Fung L, Reneker J, Myers-Mason N, Leibowitz JL, Levy $\mathrm{G}$ (1995b) Association of mouse fibrinogen-like protein with murine hepatitis virus-induced prothrombinase activity. J Virol 69:5033-5038

Pereira CA, Steffan AM, Kirn A (1984) Interaction between mouse hepatitis viruses and primary cultures of Kupffer and endothelial liver cells from resistant and susceptible inbred mouse strains. J Gen Virol 65(Pt 9):1617-1620

Petit SJ, Wise EL, Chambers JC, Sehmi J, Chayen NE, Kooner JS, Pease JE (2011) The CXCL16 A181V mutation selectively inhibits monocyte adhesion to CXCR6 but is not associated with human coronary heart disease. Arterioscler Thromb Vasc Biol 31:914-920

Le Prevost C, Levy-Leblond E, Virelizier JL, Dupuy JM (1975a) Immunopathology of mouse hepatitis virus type 3 infection. Role of humoral and cell-mediated immunity in resistance mechanisms. J Immunol 114:221-225

Le Prevost C, Virelizier JL, Dupyu J-M (1975b) Immunopathology of mouse hepatitis virus type 3 infection. III. Clinical and virologic observation of a persistent viral infection. J Immunol 175:640-643

Qureshi ST, Clermont S, Leibowitz J, Fung LS, Levy G, Malo D (1995) Mouse hepatitis virus-3 induced prothrombinase (Fg12) maps to proximal chromosome 5. Genomics 29:307-309

Rezende G, Roque-Afonso AM, Samuel D, Gigou M, Nicand E, Ferre V, Dussaix E, Bismuth H, Feray C (2003) Viral and clinical factors associated with the fulminant course of hepatitis A infection. Hepatology 38:613-618

Sainokami S, Abe K, Sato A, Endo R, Takikawa Y, Suzuki K, Okamoto H (2007) Initial load of hepatitis B virus (HBV), its changing profile, and precore/core promoter mutations correlate with the severity and outcome of acute HBV infection. J Gastroenterol 42:241-249

Sato S, Sugiyama M, Yamamoto M, Watanabe Y, Kawai T, Takeda K, Akira S (2003) Toll/IL-1 receptor domain-containing adaptor inducing IFN-beta (TRIF) associates with TNF receptorassociated factor 6 and TANK-binding kinase 1, and activates two distinct transcription factors, NF-kappa B and IFN-regulatory factor-3, in the Toll-like receptor signaling. J Immunol 171:4304-4310

Shinoda M, Wakabayashi G, Shimazu M, Saito H, Hoshino K, Tanabe M, Morikawa Y, Endo S, Ishii H, Kitajima M (2006) Increased serum and hepatic tissue levels of interleukin-18 in patients with fulminant hepatic failure. J Gastroenterol Hepatol 21:1731-1736

Stravitz RT, Lee WM (2019) Acute liver failure. Lancet 394:869-881

Taguchi F, Kawamura S, Fujiwara K (1983) Replication of mouse hepatitis viruses with high and low virulence in cultured hepatocytes. Infect Immun 39:955-959

Tang Y, Li H, Li J, Liu Y, Li Y, Zhou J, Zhou J, Lu X, Zhao W, Hou J, Wang XY, Chen Z, Zuo D (2018) Macrophage scavenger receptor 1 contributes to pathogenesis of fulminant hepatitis via neutrophil-mediated complement activation. J Hepatol 68:733-743

Tangye SG, Latour S (2020) Primary immunodeficiencies reveal the molecular requirements for effective host defense against EBV infection. Blood 135(9):644-655

Tardieu M, Hery C, Dupuy JM (1980) Neonatal susceptibility to MHV3 infection in mice. II. Role of natural effector marrow cells in transfer of resistance. J Immunol 124:418-423

Tsutsui H, Mizoguchi Y, Morisawa S (1992) Importance of direct hepatocytolysis by liver macrophages in experimental fulminant hepatitis. Hepatogastroenterology 39:553-559

Virelizier JL, Allison AC, de Maeyer E (1977) Production by mixed lymphocyte cultures of a type II interferon able to protect macrophages against virus infection. Infect Immun 17:282-285

Virelizier JL, Gresser I (1978) Role of interferon in the pathogenesis of viral diseases of mice as demonstrated by the use of anti-interferon serum. V. Protective role in mouse hepatitis virus type 3 infection of susceptible and resistant strains of mice. J Immunol 120:1616-1619

Virelizier JL, Virelizier AM, Allison AC (1976) The role of circulating interferon in the modifications of immune responsiveness by mouse hepatitis virus (MHV-3). J Immunol 117:748-753

Wijburg OL, Heemskerk MH, Boog CJ, Van Rooijen N (1997) Role of spleen macrophages in innate and acquired immune responses against mouse hepatitis virus strain A59. Immunology 92:252-258

Yalniz M, Ataseven H, Celebi S, Poyrazoglu OK, Sirma N, Bahceitoglu IH (2005) Two siblings with fulminant viral hepatitis A: case report. Acta Med (Hradec Kralove) 48:173-175 
Yang C, Chen Y, Guo G, Li H, Cao D, Xu H, Guo S, Fei L, Yan W, Ning Q, Zheng L, Wu Y (2013) Expression of B and T lymphocyte attenuator (BTLA) in macrophages contributes to the fulminant hepatitis caused by murine hepatitis virus strain-3. Gut 62:1204-1213

Yoshida Y, Okada Y, Suzuki A, Kakisaka K, Miyamoto Y, Miyasaka A, Takikawa Y, Nishizawa T, Okamoto H (2017) Fatal acute hepatic failure in a family infected with the hepatitis A virus subgenotype IB: a case report. Medicine (Baltimore) 96:e7847

Yumoto E, Higashi T, Nouso K, Nakatsukasa H, Fujiwara K, Hanafusa T, Yumoto Y, Tanimoto T, Kurimoto M, Tanaka N, Tsuji T (2002) Serum gamma-interferon-inducing factor (IL-18) and IL-10 levels in patients with acute hepatitis and fulminant hepatic failure. J Gastroenterol Hepatol 17:285-294

Zhang SY, Casanova JL (2015) Inborn errors underlying herpes simplex encephalitis: from TLR3 to IRF3. J Exp Med 212:1342-1343

Zhang SY, Clark NE, Freije CA, Pauwels E, Taggart AJ, Okada S, Mandel H, Garcia P, Ciancanelli MJ, Biran A, Lafaille FG, Tsumura M, Cobat A, Luo J, Volpi S, Zimmer B, Sakata S, Dinis A, Ohara O, Garcia Reino EJ, Dobbs K, Hasek M, Holloway SP, McCammon K, Hussong SA, DeRosa N, Van Skike CE, Katolik
A, Lorenzo L, Hyodo M, Faria E, Halwani R, Fukuhara R, Smith GA, Galvan V, Damha MJ, Al-Muhsen S, Itan Y, Boeke JD, Notarangelo LD, Studer L, Kobayashi M, Diogo L, Fairbrother WG, Abel L, Rosenberg BR, Hart PJ, Etzioni A, Casanova JL (2018) Inborn errors of RNA lariat metabolism in humans with brainstem viral infection. Cell 172:952-965

Zhang SY, Jouanguy E, Zhang Q, Abel L, Puel A, Casanova JL (2019) Human inborn errors of immunity to infection affecting cells other than leukocytes: from the immune system to the whole organism. Curr Opin Immunol 59:88-100

Zhu CL, Yan WM, Zhu F, Zhu YF, Xi D, Tian DY, Levy G, Luo XP, Ning Q (2005) Fibrinogen-like protein 2 fibroleukin expression and its correlation with disease progression in murine hepatitis virus type 3-induced fulminant hepatitis and in patients with severe viral hepatitis B. World J Gastroenterol 11:6936-6940

Publisher's Note Springer Nature remains neutral with regard to jurisdictional claims in published maps and institutional affiliations. 